\title{
Impact of Remuneration for Work on Social Changes in Lithuania
}

\author{
Boguslovas Gruževskis
}

Institute of Labour Market Research, the Lithuanian Social Research Centre

\section{Tadas Sudnickas}

Institute of Management, Faculty of Public Governance, Mykolas Romeris University

$$
\text { Jolanta Urbanovič }
$$

Institute of Public Administration, Faculty of Public Governance, Mykolas Romeris University

\begin{abstract}
Satisfaction with compensation for work in modern society, especially in welfare states, plays a very important role. It not only ensures the efficient use of available production facilities and natural resources, but also determines the size of the state budget, the quality of life in the country, an attitude towards emigration and the general state of social situation. In a market economy, wages are the expression of capital and labour relations, both at the national and at the company level. The compensation systems are also influenced by some external factors such as tax system, technological level, labour supply and demand balance and legal regulation. The article seeks to reveal how the satisfaction with pay for work affects the social changes in the country. The article present the results of the research carried out in Lithuania in 2017.
\end{abstract}

Keywords: compensation, remuneration, work, wages, social changes, Lithuania, employment

\section{Introduction}

Remuneration in modern society, especially in welfare states, plays a crucial role. It not only ensures the efficient use of means of production and available natural 
resources, but also determines the size of the state budget, the quality of life in the country, attitudes towards emigration and the general state of social situation. The system of remuneration should be equitable within the company, competitive externally and in line with the company's culture, structure and objectives. In a market economy, remuneration is the expression of the capital-labour relation, both at the national and company level, and relates an employee to the employer. Employees are interested in getting the highest remuneration possible, because satisfaction of their family needs and their own fulfilment at the workplace depend on it; meanwhile, the employer seeks to minimize the cost of remuneration to reduce the cost of production and increase competitiveness of the production or services and, consequently, increase the employer's income.

These contradictory factors determine the type of remuneration or, more precisely, compensation for work. The remuneration system is used to achieve several goals; the employer seeks to attract appropriate employees and retain the good ones, motivate good performance, wisely spend funds, reward appropriate behaviour, align the goals of employees and the organization, which is relevant for both the employer and the employees. Moreover, compensation for work, from the point of view of employees, should be adequate, i.e. it should adequately compensate for the employees' time, effort and energy allocated to perform the duties, costs for acquiring and maintaining the required qualifications, as well as costs necessary for rest and recreation. In addition to the goals of employers and employees, the state, as an arbitrator of these two parties, also raises certain requirements to the systems of compensation for work. Alongside the role of an arbitrator, the state to a significant extent carries out the functions of the employer through the structures of public administration, which in theory may lead to a certain conflict of interest. The state sets such requirements to the system of compensation for work as legality, i.e. it must be defined in law, non-discriminatory, secure for both the employer and the employee, and to guarantee the rights and agreed expectations of both parties. As M. Bloom (2004) claims, compensation systems not only are viewed as transfer of market relations into the organization, but they also allow to create effective economic exchange of labour for payment, play an important symbolic and social role in the organization, and influence employee loyalty and motivation. Recruitment relationships based on mutual interest, respect and trust result in higher organizational performance. The external factors that have a significant impact on remuneration are the tax system, the technological level of production, the balance of labour supply and demand and legal regulation. The state, as an arbitrator, is responsible for legal regulation of compensation for work. 
This article seeks to reveal what internal and external factors determine satisfaction with remuneration and motivation at work, to examine the assumptions which the satisfaction of compensation for work implies for social change and present the results of the research („Compensation justice” No 2016/21/B/HS4/02992 financed by National Science Centre, Poland) carried out in Lithuania in 2017 on equitable compensation for work.

\section{Theoretical assumptions of compensation for work}

Employee satisfaction with remuneration for work is investigated by motivation specialists. Different aspects of compensation for work are reflected in one way or another in a number of major time-tested motivational theories: J.S. Adams' theory of equality, F.B. Herzberg's motivational-hygiene theory or else called the two factor theory of motivation (Herzberg, 1968, 1974), as well as partly in the theory of V.H Vroom (1964) and Lawler's expectancy theory. Herzberg's theory, which relies on Maslow's hierarchy of needs, but is more oriented towards the working environment, assumes that job satisfaction, as well as dissatisfaction, depends on a number of factors that are divided into two categories: motivational, i.e. achievements, recognition, the very nature of work, responsibility, promotion, and hygiene, i.e. organizational policies, leadership, relations with the manager, working conditions, relations with colleagues, relations with subordinates and, ultimately, remuneration. Motivational factors motivate the employees in their own right, the absence of this factor does not cause more dissatisfaction, however, the effect of the hygiene factor is opposite - its presence does not significantly motivate us, whereas its absence strongly demotivates (Herzberg, 1971; Herzberg, Mausner, Snyderman, 2005). By ensuring all hygiene factors in the organization, it is possible to use motivational factors more effectively.

There is a number of researchers conducted on the basis of Herzberg's theory (e.g. Lundberg, Gudmundson, Andersson, 2009; Matei, Abrudan, 2016). N. Bassett-Jones and G.C. Lloyd (2005), based on their research which involved more than 3000 respondents from 32 organizations, approached Herzberg's theory critically. Respondents were divided into two groups: those who are more motivated by internal motivation (motivators), and those who are more motivated by external factors (movers). The research results showed that internal motivators outweighed the factors associated with external motivators, one of which is the financial incentive.

J.S. Adams, a psychologist who analysed human behaviour in workplace, in 1963 outlined his attitude to motivation, which he called the theory of equality 
(Adams, 1963, 1965). We all seek a fair relationship between what we put into our work and what we get from it. J.S. Adams refers to this as input and output. The perception whether this relationship is adequate is attained by observing the environment and comparing one's own situation with the situation of other employees. Input is employee's efforts, loyalty, hard work, dedication, skills, abilities, flexibility, adaptability, tolerance, determination, enthusiasm, trust in leadership, support for colleagues and subordinates, and self-sacrifice for the benefit of the organization. Output is remuneration, bonuses, reward, commission, reputation, recognition, praise and gratitude, incentives, entrusted responsibility, training, and career (see also Huseman, Hatfield, Miles, 1987; Shore, 2004; Brooks, 2009).

The expectancy theory, introduced in 1964 by V.H. Vroom and developed by E. Lawler and L. Porter in 1968 (Vroom, 1964; Lawler, Porter, 1968), assumes that each person chooses how to behave in a situation depending on the expected result, in other words, everyone strives to make choices to minimize unpleasant feelings and maximize pleasure (see also Eerde van, Henk, 1996). Expectancy theory is generally supported by empirical evidence (e.g. Vansteenkiste et al., 2005; Chiang, Jang, 2008) and is one of most commonly used theories of motivation in the workplace. According to the expectancy theory, motivation can be represented by the following formula:

$$
\text { Motivation = Expectancy } \mathrm{x} \text { Valence } \mathrm{x} \text { Instrumentality, }
$$

where:

Expectancy - belief that efforts put into work will be rewarded by success (How much effort should be made to achieve the desired result?), Valence - value of the outcome for the person (What is the reward for the work performance?),

Instrumentality - the probability that the expected reward will be obtained upon reaching the result (Will my efforts be noticed?).

The higher each of the constituent elements is, the greater motivation is. For example, if an employee wants to climb the career ladder, promotion is of high valence for him/her; if an employee expects his/her labour productivity will ensure work performance, his/her expectancy is high, but if he/she does not feel that the management is likely to assign this post to the employee and will start looking for someone from outside the company, such employee will not think that this measure is suitable to achieve his/her purpose and he/she will not be motivated to make more efforts. 


\section{Social consequences of inadequate remuneration for work}

In the context of social development, assessment of remuneration for work in Lithuania should rely on three main attributes: 1 ) the average salary is one of the lowest in the EU (EU, 2018); 2) the pay gap between executives and workers is among the highest in the EU (Verslo žinios, 2014); 3) the correlation between economic growth (GDP growth) and wage changes is inadequate (OECD, 2018). Problems with remuneration in Lithuania started after the crisis of 2008-2009, when about 120 thousand employees lost their jobs, salaries of public sector employees were reduced by $15 \%$, and pensions and social benefits were reduced. Although the country's economy recovered since 2011, despite the increase in labour productivity, the average wage declined until 2014 (ETUI, 2015).

Figure 1. Average wages (net) EU 2017 (EUR)

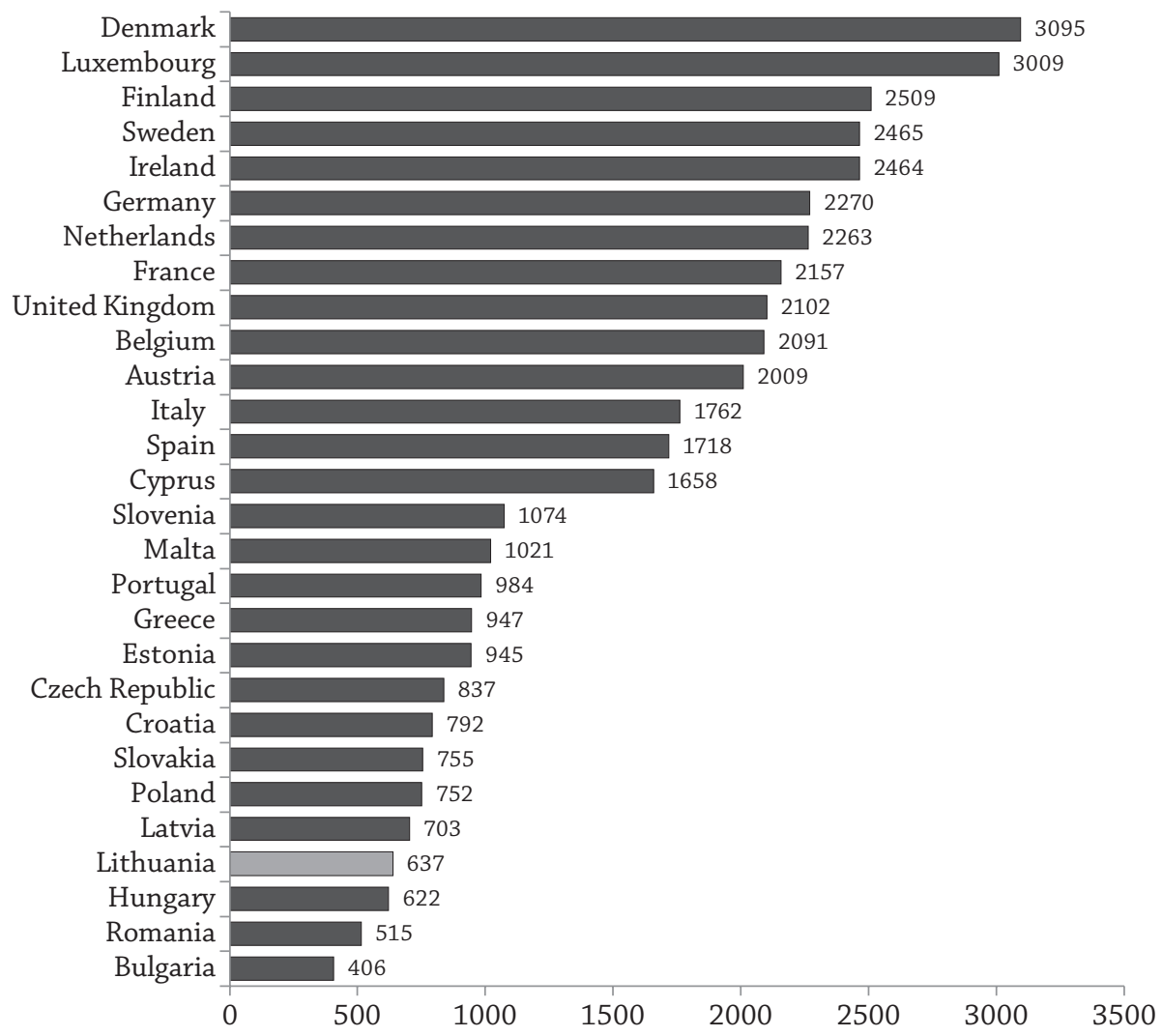

Source: EU (2018). 
Since 2015 salaries in Lithuania have started to grow, however they have lagged behind Estonia significantly, which has a similar economic potential (GDP per capita in PPS is about $75 \%$ of the EU average). Lithuania has lagged behind Poland and Latvia as well, although it is ahead of these countries according to the economic potential (Eurostat).

A significant difference in compensation for work between executives and ordinary employees has a negative impact on satisfaction of the population with remuneration in Lithuania. According to the results of the study conducted by Hay Group in 2014 (Verslo žinios, 2014), in Lithuania, a worker's salary is on average 7.4 times lower than the salary of a director. This difference is particularly significant, as, for example, in Great Britain this figure is 3.4 times, in Estonia it is 6.2 times. Taking into account the results of this study, it can be argued that low average salary in the country reveals only a part of problems faced by Lithuanian residents in the area of remuneration in reality.

For these reasons, since 2015 Lithuania has had the highest level of income inequality in the $\mathrm{EU}^{1}$ (Figure 2), one of the highest levels of emigration in the $\mathrm{EU}^{2}$, and the increasing shortage of skilled workers.

Figure 2. Differentiation of disposable income (Gini coefficient), EU, 2015

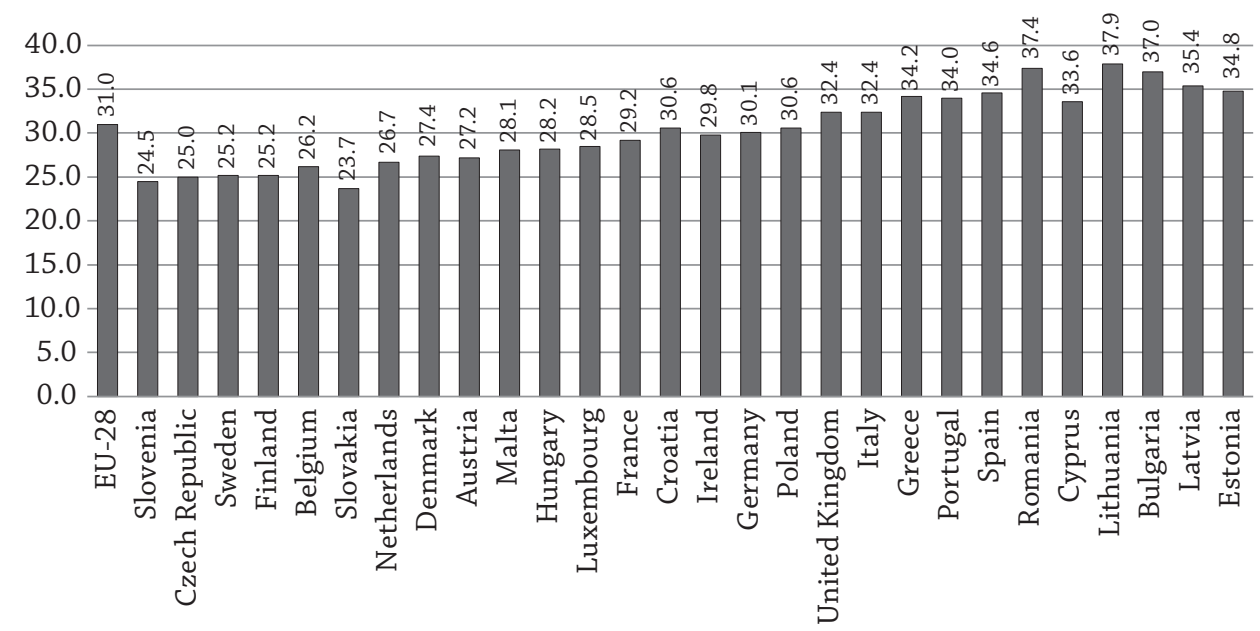

Source: Differentiation of disposable income. http://ec.europa.eu/eurostat/statistics-explained/index.php/ Income_distribution_statistics

\footnotetext{
1 Statistics Lithuania 2017; Eurostat 2017.

2 IOM Lietuva. http://www.iom.lt/lt/kas-mes-/tmo-lietuvoje
} 
Low wages and a high level of income inequality determine the fact that a large part of the country's population faces precarious employment. In comparison with other EU member-states, precarious employment in Lithuania is well above the average of the EU countries (EU-28). Precarious employment increased significantly during the post-crisis period in 2011-2012, whereas recently it has decreased to the pre-crisis level ${ }^{3}$ (Figure 3 ).

Figure 3. Precarious employment in Lithuania and the European Union (EU-28) (\%)

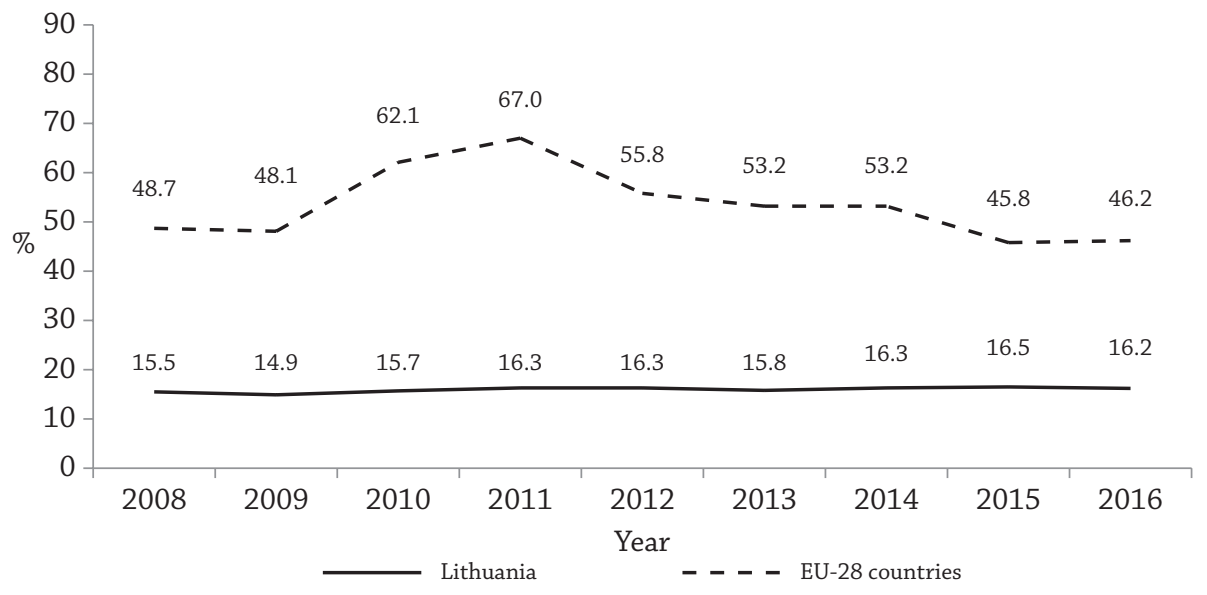

Source: Gruževskis, Brazienè (2017).

Precarious employment is quite widespread in Lithuania and this has a negative impact on the attractiveness of the Lithuanian labour market - both for satisfaction of employees and the efficiency of their work, and the standard of living in the country. Due to low salaries and low social dialogue in enterprises and organizations and lack of trade collective agreements, precarious employment covers the entire labour market irrespective of employment forms (though it is less common in IT, finance, insurance, and real estate economic activities).

The risk of precarious employment is three times higher in Lithuania than in the EU on average. Representatives of certain socially more vulnerable groups, i.e. women, the youth, elderly people, people with disabilities, are more likely to be subject to precarious employment (Gruževskis, Brazienè, 2017).

For a long time, dissatisfaction with remuneration has been the key factor in encouraging Lithuanians to emigrate from the country and seek better working conditions. According to the survey carried out in 2006 (VPVI, 2006), the main

3 Eurostat research on labour force (Eurostat LFS). 
push factor from Lithuania was low remuneration. The second most important push factor from Lithuania was the fact that pay was not performance-related. Public sector employees felt insufficiently appreciated, i.e. they performed certain functions for which they did not receive appropriate remuneration. According to the survey carried out in 2014 (Žvalionytè, 2014), the situation did not change and $52 \%$ of emigrants from Lithuania indicated that the main push factor for them was low, inadequate remuneration.

The intense emigration of the Lithuanian inhabitants has a very negative impact not only on the labour market of the country, but also on the total population and the aging process. According to the United Nations data, if the situation does not change as such, in 2050, only about 2.3 million inhabitants will live in the country (in 1989 there were 3.5 million inhabitants). The World Bank claims that Lithuania falls among the world's three most demographically disadvantaged countries (the population is falling faster only in Puerto Rico and Latvia) (Žibas, Lekavičiūtè, 2017).

The most important reason for the decline in the population in Lithuania is emigration (Table 1). It is important to emphasize the fact that the emigration flows in Lithuania have been intense, while immigration of foreigners remains small, thus it cannot compensate for the loss of those who left Lithuania (as is the case, for example, in Poland). In the period from 2001 to 2011, the country's population decreased by 440.6 thousand (12.6\%). The decrease in population was mainly due to emigration (76.9\%). Over a decade, 402.9 thousand people left the country, and only 64.2 thousand arrived (23.1\%) (Stankūnienė et al., 2016).

Table 1. Survey of emigrants by reason for leaving (respondents were asked to indicate a single answer)

\begin{tabular}{|l|c|}
\hline \multicolumn{1}{|c|}{ Reason for emigration } & \% of respondents \\
\hline Wanted to earn more; Lithuanian salaries are unsatisfactory & 52.2 \\
\hline Could not find work in Lithuania, needed a source of income & 24.3 \\
\hline For educational purposes (to carry out research/for an internship, etc.) & 7.2 \\
\hline Wanted to try their abilities, experience new things & 3.9 \\
\hline Due to family related reasons & 4.6 \\
\hline Inability to pay back bank loans and other financial commitments & 3.2 \\
\hline Sought better working conditions & 2.2 \\
\hline Disappointed with perspectives in Lithuania & 0.7 \\
\hline Other reasons & 1.7 \\
\hline Total & 100.0 \\
\hline
\end{tabular}

Source: Žvalionytė (2014). 
Although the return migration of the Lithuanian population is increasing, it does not essentially solve the country's demographic challenges. According to the European Migration Network, almost $72 \%$ of people departing from Lithuania are 15-44 years old, which means that people of working age are leaving the country. The decline in the number of young people caused by emigration poses serious challenges such as a decline in the number of marriages and birth rates, the growing demand for labour, whereas the decreasing number of the employed have to support the rising numbers of the unemployed (EMN, 2017).

\section{Research methodology and results}

An empirical study was carried out to assess the impact of the amount of remuneration on the employee satisfaction, and perception of remuneration equitability. The study was conducted based on a quantitative survey method. The sample consists of citizens of Lithuania aged over 18 who work in different sectors of economy, in different positions, in different regions of Lithuania. The selection was based on non-probability sampling of typical members. The survey was conducted via an online random sampling method. The study used the networks of various trade unions operating in Lithuania. 1087 responses were used for data analysis.

Figure 4. Employee satisfaction with the remuneration

My remuneration satisfies me

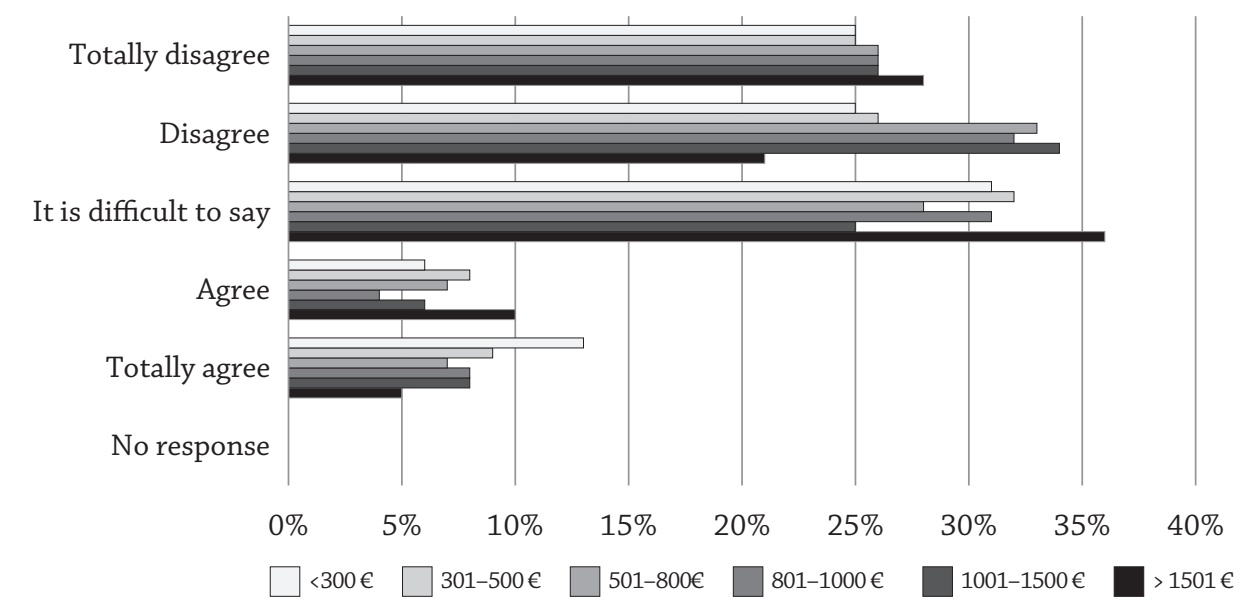

Source: Authors' own calculations based on Compensation Justice Survey, 2017. 
The average score of the responses to the survey questions (possible answers to questions were formulated on the Likert scale from 1 to 5), reveals how the respondents evaluate their satisfaction and remuneration equitability. For convenience, employees who fall under six different salary intervals were further grouped into three major categories: those who receive a minimum wage (up to $300 \mathrm{EUR}$, those who receive an average and lower than average salary (300 to 800 EUR), and those who receive a salary higher than average (more than $800 \mathrm{EUR}$ ).

As we can see from the chart, $86 \%$ of the surveyed employees disagree or totally disagree with the statement that they are satisfied with their salary. Only $6 \%$ of the respondents who receive a minimum wage are satisfied with it; only $3 \%$ of those who receive an average and lower salary are satisfied with it; and the share of the satisfied respondents among those who receive higher than the average salary is $10 \%$.

Figure 5. Change of the workplace due to small remuneration

I want to change the workplace due to small remuneration

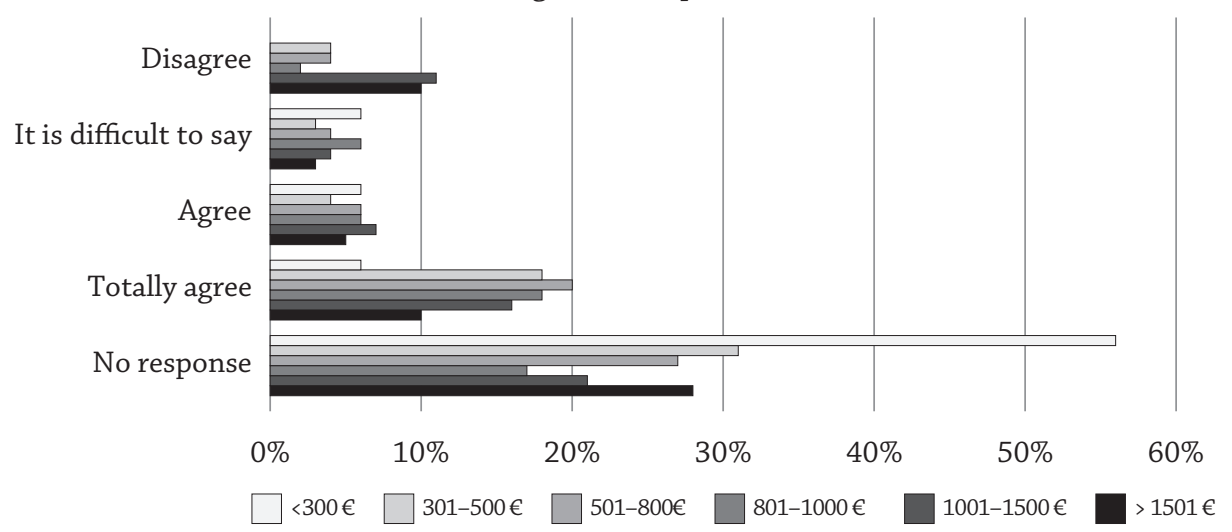

Source: The authors' calculations based on Compensation Justice Survey, 2017.

$44 \%$ of the respondents want to change jobs because of low pay, namely $62 \%$ of those who receive a minimum wage, $48 \%$ of those who receive an average and lower salary, and $36 \%$ of those who receive higher than the average salary.

$86 \%$ of the respondents indicated that the most important factor in their work is remuneration; this statement was supported by $94 \%$ of the respondents who receive the minimum wage, $84 \%$ of the respondents who receive average and lower salary, and $89 \%$ of the respondents who receive higher than the average salary.

$29 \%$ of the respondents indicated that remuneration policy in their company is open/transparent. Only $12 \%$ of the respondents who receive a minimum wage 
agree or totally agree with the statement, $28 \%$ of those who receive average and lower salary, and $32 \%$ of those who receive higher than the average salary.

Figure 6. Importance of remuneration

The most important factor at work for me is remuneration

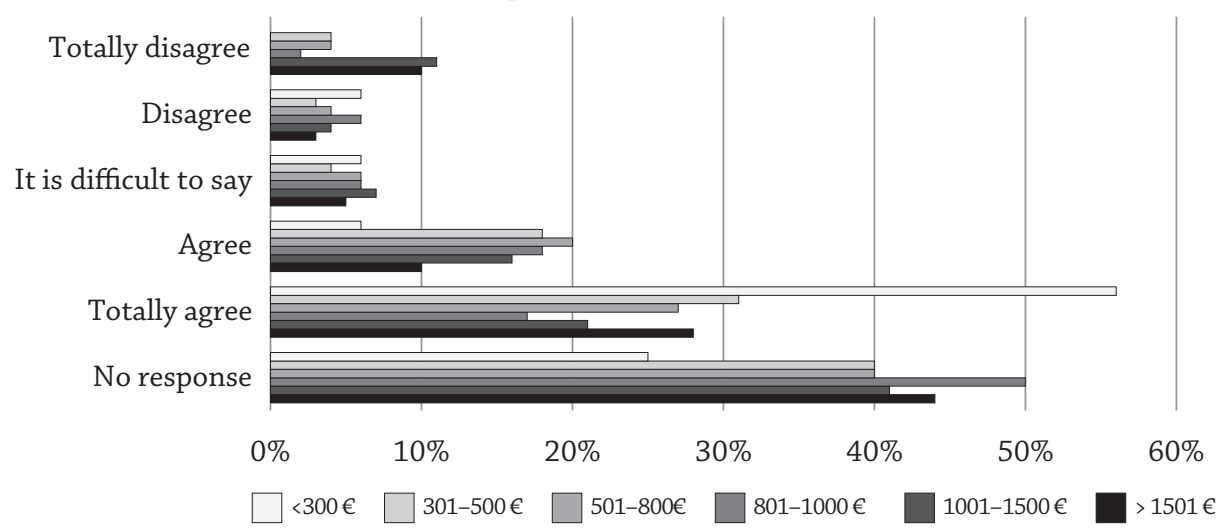

Source: The authors' calculations based on Compensation Justice Survey, 2017.

Figure 7. Remuneration policy in enterprises

Remuneration policy in my company is open/transparent

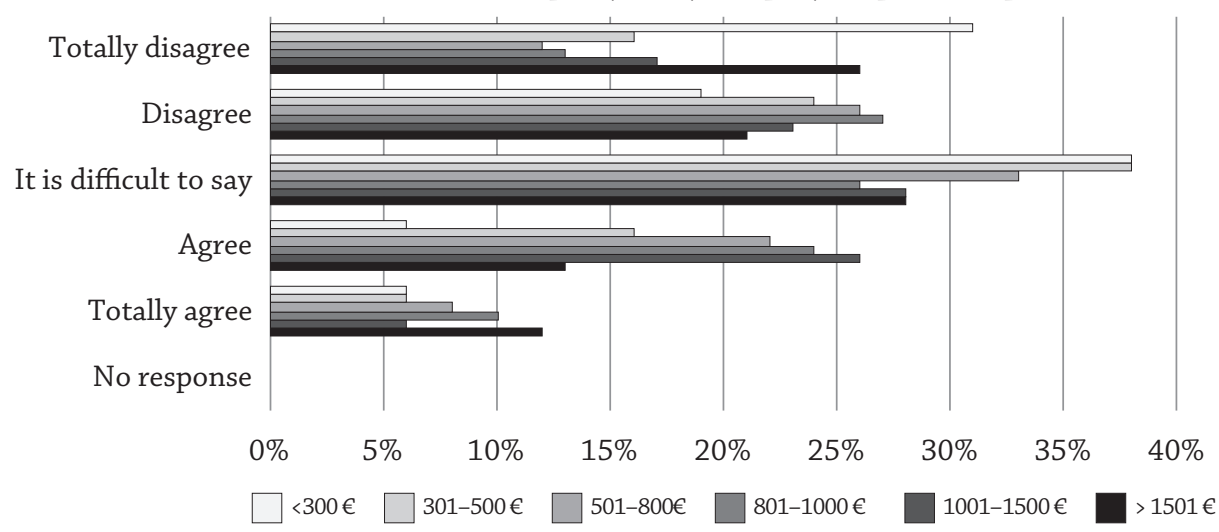

Source: The authors' calculations based on Compensation Justice Survey, 2017.

$25 \%$ of the respondents indicated that they agree or totally agree with the statement that their line manager ensures equitable remuneration to the employees, 39\% do not agree, whereas $37 \%$ find it difficult to say. This statement was supported by $26 \%$ of the respondents who receive a minimum wage, $22 \%$ of the respondents who receive average and lower salary, and $30 \%$ of the respondents who receive higher than the average salary. 
Figure 8. Involvement of the line manager in ensuring equitable remuneration

My line manager ensures equitable remuneration to the employees

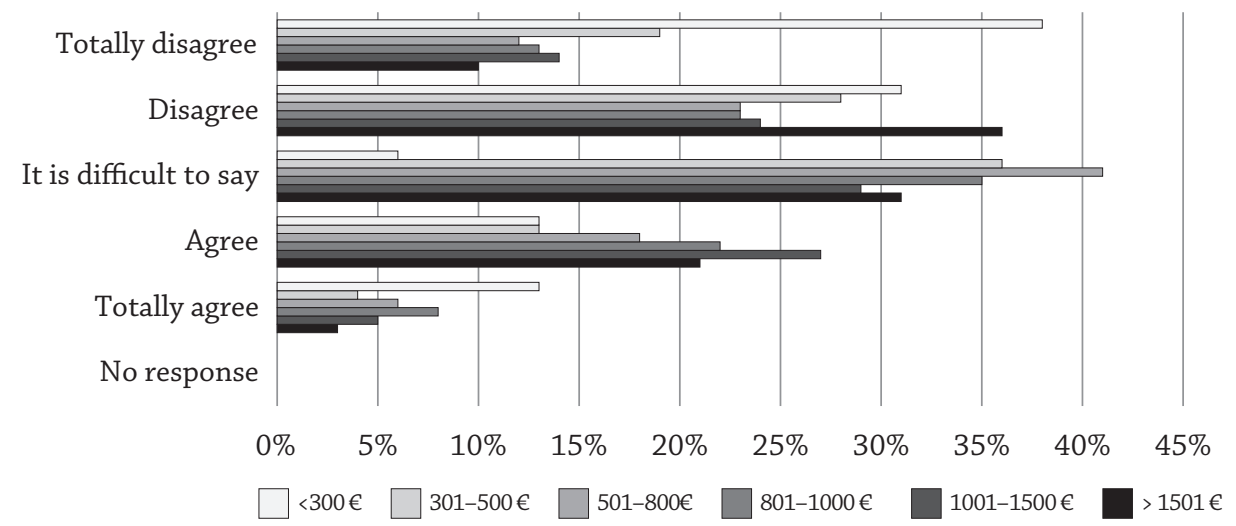

Source: The authors' calculations based on Compensation Justice Survey, 2017.

Figure 9. Conformity of remuneration and work performed

My remuneration corresponds to the work performed

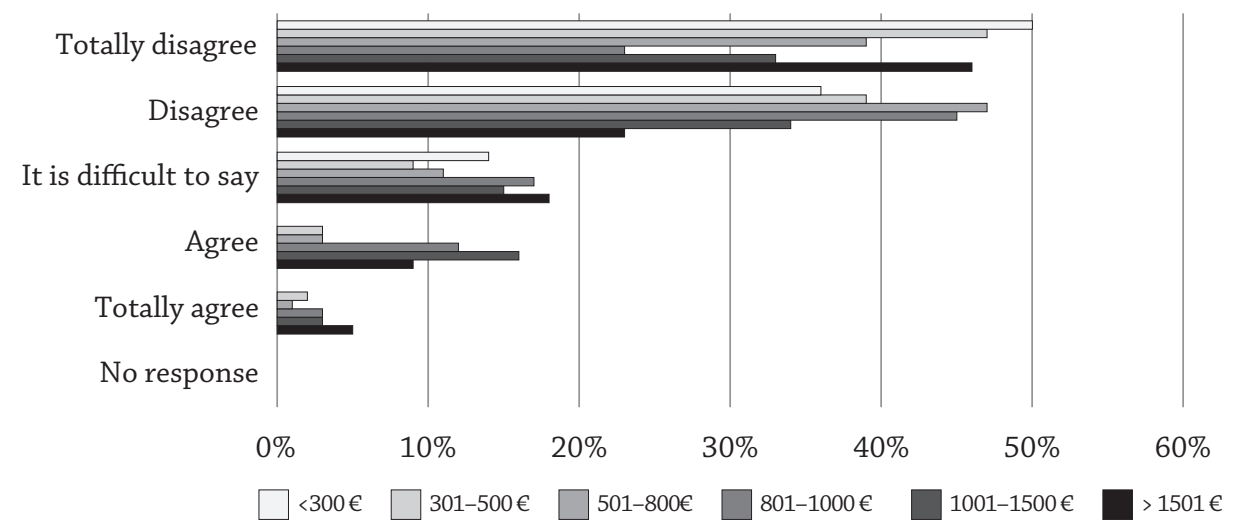

Source: The authors' calculations based on Compensation Justice Survey, 2017.

$7 \%$ of the respondents indicated that they agree or totally agree with the statement that their remuneration corresponds to the work performed, whereas $81 \%$ of the respondents disagree or totally disagree with the statement. None of the respondents who receive a minimum wage agree with the statement. This statement was supported by $4 \%$ of the respondents who receive average and lower salary, and $16 \%$ of the respondents who receive higher than the average salary.

$9 \%$ of the respondents indicated that they agree or totally agree with the statement that their remuneration is equitable, $75 \%$ of the respondents do not agree with the statement. None of the respondents who agree with the statement 
receive a minimum wage. This statement was supported by $6 \%$ of the respondents who receive average and lower salary, and $2 \%$ of the respondents who receive higher than the average salary.

\section{Figure 10. Assessment of equitable remuneration}

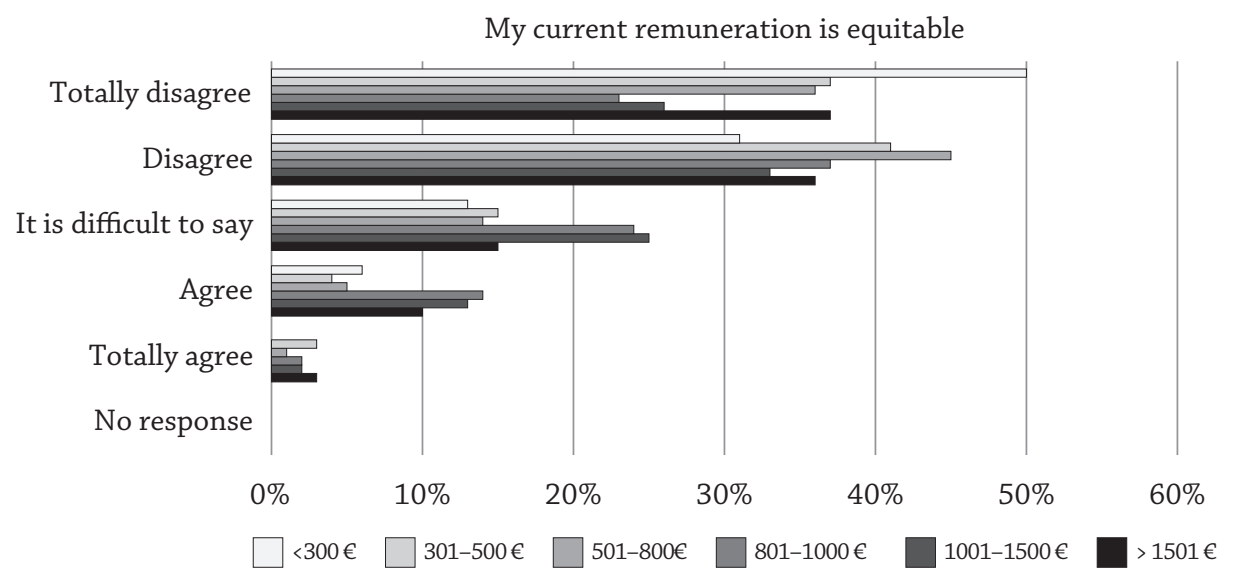

Source: The authors' calculations based on Compensation Justice Survey, 2017.

\section{Figure 11. Assessment of exploitation at work}

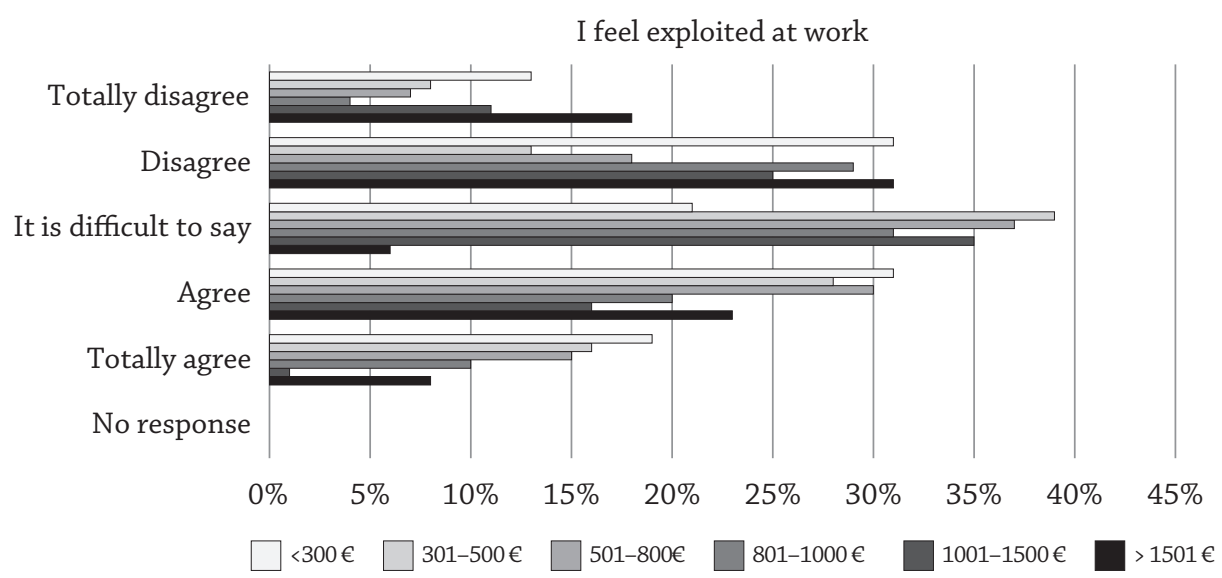

Source: The authors' calculations based on Compensation Justice Survey, 2017.

$40 \%$ of the respondents feel exploited at work. This statement was supported by $50 \%$ of the respondents who receive a minimum wage, $45 \%$ of the respondents who receive average and lower salary, whereas those who receive higher than the average salary constitute 30\% (801-1000 EUR), 17\% (1001-1500 EUR) and 31\% (more than 1500 EUR) respectively. 
$49 \%$ of the respondents agree with the statement that employees who perform similar functions receive similar remuneration. This statement was supported by $31 \%$ of the respondents who receive a minimum wage, $22 \%$ of the respondents who receive average and lower salary, whereas those who receive higher than the average salary constitute 53\% (801-1000 EUR), 43\% (1001-1500 EUR) and 41\% (more than 1500 EUR) respectively.

Figure 12. Assessment of remuneration in terms of equality

Employees who perform similar functions receive similar remuneration to mine

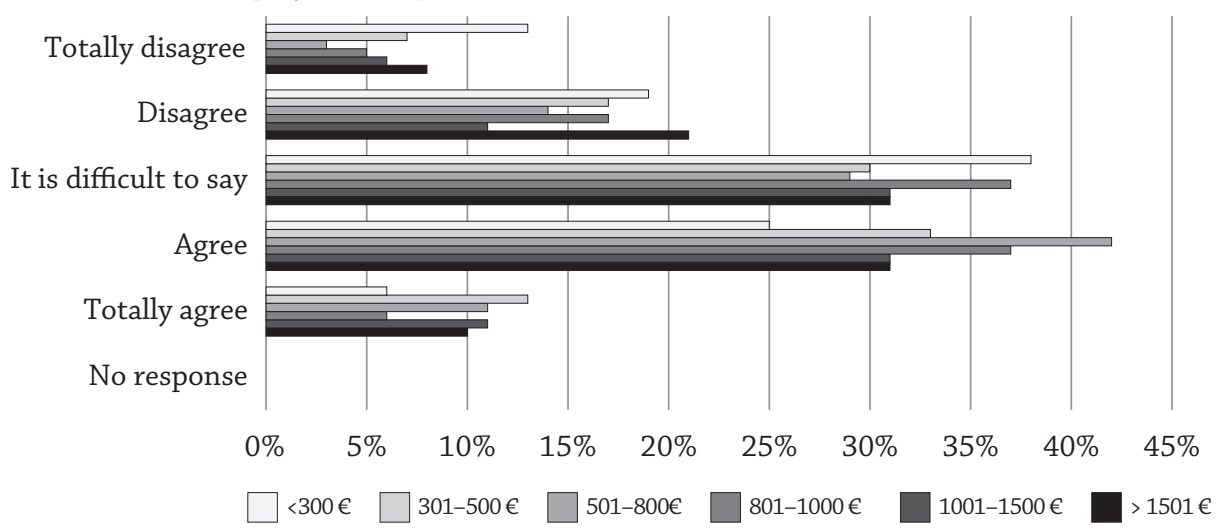

Source: The authors' calculations based on Compensation Justice Survey, 2017.

The results of the survey reveal that satisfaction and perception of equitable remuneration of the majority of the respondents is proportionally dependent on the amount of remuneration received. The higher the remuneration is, the higher the satisfaction and the higher the assessment of the equitable payment for work are. There were exceptions to the answers to the questions about whether the salary satisfies the employee and whether the line manager ensures equitable remuneration for the employees. In this case, employees who receive average and lower salaries had a more negative attitude than those who receive a minimum wage or higher than the average salary. In one case, employees who receive average and lower salaries gave more positive answers to the question whether their remuneration is equitable, than those who receive a minimum wage or higher than the average salary.

\section{Discussion and conclusions}

The choice of a job and its attractiveness to a person is most often determined by salary. Researchers interpret salary not only as remuneration for the work done, 
but also claim that it must be consistent with the quantity and quality of work, the current market conditions, i.e. it must be sufficient to satisfy personal needs (Diamond, 2011).

The research results confirmed Herzberg's theory based on Maslow's hierarchy of needs that hygiene factors, including fair salary, must be satisfied first. The research results showed that the majority of the respondents view salaries as most important in their work (Figure 6), however the remuneration they receive is not satisfactory (Figure 4), therefore, it can be assumed that this leads to their readiness to change the company in which they work (Table 5) or to leave the country (Table 1). This is further confirmed by the fact that those who are willing to change their job receive a lower salary.

These results differ from the results of the study conducted in the UK by N. Bassett-Jones and G.C. Lloyd (2005), which showed that internal motivators outweighed the factors associated with external motivators, one of which is financial incentive. It is likely that these differences in research conducted in different countries are determined by a wider external context: the factors of satisfaction and motivation vary depending on the quality of life and the standard of living in the country.

Assessment of the obtained results from the point of view of Adams' theory of equality implies that equality and equity in terms of remuneration both in organizations and at the national level have not yet been implemented in Lithuania. Previous research (e.g. VPVI, 2006) shows that one of the main factors of emigration of skilled public sector employees from Lithuania is the fact that remuneration is not related with actual performance. On the other hand, as statistical indicators of Lithuania show, Lithuania still has a high level of differentiation of remuneration for work between executives and ordinary employees (Figure 2). The survey responses indicate a better situation at the organization level, as a large proportion of the respondents claim that employees who perform similar job functions receive a similar salary (Figure 12), however, it should be noted that a significant proportion of the respondents feel exploited at work (Figure 11), do not feel safe and supported by the line manager (Figure 8). Low salaries, lack of social dialogue in companies and organizations, and absence of trade collective agreements lead to the fact that a large part of the country's population faces precarious employment, which covers the entire labour market regardless of forms of employment.

Thus, according to the research results, more attention should be paid to the fact that the state regulation of the labour market is a crucial factor, especially in developing economies. Statistical data of Lithuania and the research results show that wage inequalities, dissatisfaction with the received remuneration and the feeling of insecurity lead to negative social and economic consequences, such as 
emigration, passivity of citizens, decline in labour productivity, etc. Therefore, it is the responsibility of the state to provide for and ensure the implementation of the principles of equitable compensation for work.

\section{References}

Adams, J.S. (1965). Inequity in social exchange. Advances in Experimental Social Psychology, 226-299.

Adams, J.S. (1963). Toward an understanding of inequity. Journal of Abnormal Psychology, 67, 422-436.

Bassett-Jones, N., Lloyd, G.C. (2005). Does Herzberg's motivation theory have staying power? Journal of Management Development, 24(10), 929-943.

Bloom, M. (2004). The Ethics of Compensation Systems. Journal of Business Ethics, 52(2), 149-152.

Brooks, I. (2009). Organisational Behaviour - Individuals, Groups and Organisation. $4^{\text {th }}$ edition. Upper Saddle River, NJ: Prentice Hall/Pearson Education.

Chiang, C.H., Jang, S.C. (2008). An expectancy theory model for hotel employee motivation. International Journal of Hospitality Management, 27(2), 313-322.

Diamond, P. (2011). Unemployment, Vacancies, Wages. American Economic Review, 101, 1045-1072.

Eerde van, W., Henk, T. (1996). Vroom's expectancy models and work-related criteria: A meta-analysis. Journal of Applied Psychology, 81(5), 575-586.

EMN (2017). European Migration Network Studies. The Effectiveness of Return in Lithuania: challenges and good practices linked to EU rules and standards. http://emn. lt/category/tyrimai/studijos/ (20.04.2018).

ETUI (2015). Benchmarking. Working Europe. 2015. Brussels.

EU (2018). Average Salary in European Union 2018. https://www.reinisfischer.com/ average-salary-european-union-2018 (28.05.2018).

Eurostat. http://ec.europa.eu/eurostat/tgm/table.do?tab=table\&init=1\&language= en\&pcode=tec00114\&plugin=1 (28.05.2018).

Gruževskis, B., Brazienè, R. (2017). Nesaugus užimtumas ir jo pokyčių tendencijos /Precarious employment and trends of its change. Lietuvos socialine raida, 6, 170-192.

Herzberg, F. (1974). Motivation-hygiene profiles: Pinpointing what ails the organization. Organizational Dynamics, 3(2), 18-29.

Herzberg, F. (1968). One more time: how do you motivate employees. Harvard Business Review, 46(1), 53-62.

Herzberg, F. (1971). Work and the nature of man. New York: World Publishing.

Herzberg, F., Mausner, B., Snyderman, B.B. (2005). The motivation to work. New Jersey: Transaction Publishers. 
Huseman, R.C., Hatfield, J.D., Miles, E.W. (1987). A new perspective on equity theory: The equity sensitivity construct. Academy of Management Review, 12, 222-234.

Lawler, E.E., Suttle, J.L. (1973). Expectancy Theory and Job Behavior. Organizational Behavior and Human Performance, 9(3), 482-503.

Locke, E.A., Latham, G.P. (2002). Building a practically useful theory of goal setting and task motivation. American Psychologist, 57, 705-717.

Lundberg, Ch., Gudmundson, A., Andersson, T.D. (2009). Herzberg's Two-Factor Theory of work motivation tested empirically on seasonal workers in hospitality and tourism. Tourism Management, 30(6), 890-899.

Matei, M.C., Abrudan, M.M. (2016). Adapting Herzberg's Two Factor Theory to the Cultural Context of Romania. Procedia - Social and Behavioral Sciences, 221(7), 95-104.

OECD (2018). OECD Reviews of Labour Market and Social Policies, Lithuania. https:// read.oecd-ilibrary.org/social-issues-migration-health/oecd-reviews-of-labourmarket-and-social-policies-lithuania_9789264189935-en\#page4 (28.05.2018).

Porter, L.W., Lawler, E.E. (1968). Managerial attitudes and performance. Homewood, IL: Irwin.

Shore, T.H. (2004). Equity sensitivity theory: do we all want more than we deserve? Journal of Managerial Psychology, 19(7), 722-728,

Stankūnienè, V., Baublytè, M., Žibas, K., Stumbrys, D. (2016). Lietuvos demografine kaita: ka atskleidžia gyventoju surašymai? (Demographic Change in Lithuania: What has the Censuses Revealed?). Vytauto Didžiojo universitetas: Kaunas.

Story, P.A., Hart, J.W., Stasson, M.F., Mahoney, J.M. (2008). Using a two-factor theory of achievement motivation to examine performance-based outcomes and self-regulatory processes. Personality and Individual Differences, 46(4), 391-395.

Vansteenkiste, M., Lens, W., Witte De, H., Feather, N.T. (2005). Understanding unemployed people's job search behavior, unemployment experience and well-being: A comparison of expectancy-value theory and self-determination theory. British Journal of Social Psychology, 44(2), 268-286.

Verslo žinios (2014). Atotrūkis tarp vadovu ir pavaldiniu atlyginimu - vienas didžiausiu (Haygroup research on remuneration). https://www.vz.lt/archive/article/2014/3/31/ atotrukis-tarp-vadovu-ir-pavaldiniu-atlyginimu-vienas-didziausiu (21.03.2018)

VPVI (2006). Lietuvos integracijos i ES poveikis kvalifikuotu Lietuvos viešojo sektoriaus darbuotoju išvykimui dirbti $\mathfrak{i}$ užsieni (The Impact of Lithuanian Integration into the EU on Emigration of Skilled Staff of the Lithuanian Public Sector to Work Abroad). https://www.urm.lt/uploads/default/documents/uzienio_politika/ES/ ES_tyrimai/8_\%20Darbo_rinka_santrauka.pdf (07.05.2018).

Vroom, V.H. (1964). Work and motivation. New York: Wiley.

Žibas, K., Lekavičiūtè, E. (2017). Darbo migracijos procesai Lietuvoje (Labor migration processes in Lithuania). Lietuvos socialine raida, 6, 54-70.

Žvalionytė, D. (2014). Grįžusių migrantų integracija kilmès šalies darbo rinkoje: Lietuvos atvejo analize (The integration of return migrants in their home country's labour 
market: Evidence from Lithuania). Daktaro disertacija (Doctoral thesis). Vilnius University: Vilnius.

\section{Prof. Boguslavas Gruževskis}

Currently Head of the Institute of Labour Market Research of Lithuanian Social Research Centre, professor of Vilnius University. He provides more than 25 years of experience in working with public administrations on national/international and local/regional level managing several projects on the labour market both at research and policy design level, as well as in the field of labour market policy, vocational training, social inclusion, social security, personal wellbeing and HRD. He is very well familiarised with the policy of the EU in the field of employment being a Lithuanian member of the EEPO (before EEO) SYSDEM network from 2003.

\section{Prof. Tadas Sudnickas}

Currently Head of the Institute of Management of Faculty of Public Governance of Mykolas Romeris University. He specializes in human resource management, performance measurement, competence management, process improvement, and leadership. He is the author and co-author of 2 monographs, 3 textbooks, scientific studies, many scientific articles published in the Lithuanian, Spanish, Latvian, Polish, Slovakian, and Kazakh scientific journals. He worked in consulting companies in Lithuania, Germany and the USA, where he conducted consulting and training projects. He trained in the Netherlands, Germany and Italy.

\section{Prof. Jolanta Urbanovič}

Currently Vice-dean of the Faculty of Public Governance at Mykolas Romeris university (MRU), professor of Public Administration Institute. Courses delivered at MRU: Administration of Education Institutions, Educational Policy, Public Administration Theories. Her research focuses on education policy and management, leadership, public governance. 